\title{
IMPLEMENTASI KOLABORASI ORANG TUA DAN GURU DALAM PELAKSANAAN PEMBELAJARAN DARING PADA PAUD
}

\author{
Moch. Surya Hakim Irwanto ${ }^{1}$
}

${ }^{1}$ Institute University of Islamic Al Khoziny Sidoarjo, Indonesia

\begin{tabular}{|c|c|}
\hline (A) Check for updates open Oaccess cC) (1) (2) & \\
\hline Sections Info & ABSTRACT \\
\hline Article history: & \multirow{10}{*}{$\begin{array}{l}\text { In current conditions it is highly recommended for all educational institutions to carry } \\
\text { out online or online-based learning. Online implementation is carried out without } \\
\text { meeting face to face with students. However, online implementation in PAUD really } \\
\text { requires active participation from parents because of the condition of students who } \\
\text { have not fully been able to access the media in online implementation. The purpose of } \\
\text { this study is to describe online learning based on collaboration between parents and } \\
\text { teachers in early childhood education. The method in this research is using descriptive } \\
\text { qualitative research. The results of this study are expected that parents will be more } \\
\text { motivated to take a proactive role in the learning process of children through online } \\
\text { learning based on collaboration between parents and teachers. }\end{array}$} \\
\hline 042020 & \\
\hline 152020 & \\
\hline Published online: Juni 302020 & \\
\hline Keywords: & \\
\hline Learning & \\
\hline Online & \\
\hline Collaboration & \\
\hline & \\
\hline & \\
\hline
\end{tabular}

\section{INTRODUCTION}

Pada keadaan sekarang ini pandemi virus corona talah berdampak pada semua aspek kehidpan masyarakat. Pendidikan menjadi salah satu kegiatan yang terdampak oleh wabah ini. Banyak dari beberapa instansi pendidikan yang memutar otak dalam melakukan kegiatan ini. Tentunya sesuai dengan anjuran pemerintah yang mengatakan pembelajaran diganti dengan sistem daring atau online. Pembelajaran online secara keseluruhan dianggap dapat mengatasi penularan dari wabah ini serta menjadi solusi yang tepat agar proses pendidikan tetap berjalan dengan baik. Namun apakah pembelajaran daring dapat optimal pada instansi pendidikan anak usia dini. Tentu ada dampak positif dan negatifnya. Banyak dari guru pendidik yang kesulitan dan kualahan dalam melaksanakan proses pembelajaran daring. Salah satunya adalah kurangnya sarana dan prasarana yang dimiliki siswa atau orang tua. Pembelajaran menjadi tidak efektif dikarenakan sifat pembelajaran hanya bersifat instruktif bukan membimbing. Ketidaksuksesan dalam penerapan metode yang sesuai dikarenakan adanya miskomunikasi antara guru dan orang tua. Namun tidak dapat menjadi alasan untuk melaksanakan pendidikan yang sudah menjadi tanggung jawab guru. Guru harus menggunakan metode yang tepat sehingga proses pembelajaran dapat terlaksana dengan baik. Salah satu cara yang dapat dilakukan oleh guru adalah dengan kolaborasi antara guru dengan orang tua.

Dimana guru memberikan instruksi dan orang tua menjadi tonggak dalam menjelaskan dan melaksanakan maksud dari instruksi kepada anak. Kolaborasi antara guru dengan orang tua sangatlah penting karena pada anak usia dini masih belum dapat menerima instruksi guru dengan sangat jelas karena kurangnya pengalaman dan pengetahuan proses pelaksanaan daring. Serta kemampuan pada anak usia dini masih sangat terbatas dalam memahami suatu perintah yang mana bisa dikatakan kemampuan kognitif dan mental anak usia dini belum berkembang dengan sangat baik. Maka dari itu harus ada peran dari orang tua dalam membantu pelaksanaan pembelajaran daring ini. Pembelajaran daring merupakan suatu pembelajaran tanpa bertatap muka secara 
langsung dengan menggunakan media online sebagai sarana pembelajaran. Bisa dikatakn pembelajaran daring adalah sebuah pembelajaran yang dilakukan tidak dengan interkasi KBM secara langsung melainkan dengan perantara media komunikasi yang berbasis internet.

Lembaga Pendidikan Anak Usia Dini di Indonesia telah diatur dalam UndangUndang Dasar 1945 pasal 28 B ayat 2 yang menyatakan bahwa setiap anak berhak atas kelangsungan hidup, tumbuh dan berkembang serta berhak untuk mendapatkan perlindungan dari kekerasan dan diskriminasi. Serta Undang-undang No. 23 Tahun 2002 pasal 9 ayat 1 tentang Perlindungan Anak menyatakan bahwa setiap anak berhak memperoleh pendidikan dan pengajaran dalam rangka pengembangan pribadinya dan tingkat kecerdasan sesuai dengan minat dan bakatnya. Dalam Undang-undang Nomor 20 Tahun 2003 tentang Sistem Pendidikan Nasional dengan tegas menjelaskan perlunya penanganan pendidikan anak usia dini. Yang mana mejelaskan dalam Pasal 1 ayat 14 bahwa Pendidikan Anak Usia Dini adalah suatu upaya pembinaan yang ditujukan kepada anak sejak lahir sampai dengan usia enam tahun yang dilakukan melalui pemberian stimulasi pendidikan untuk membantu pertumbuhan dan perkembangan jasmani dan rohani agar anak memiliki kesiapan dalam memasuki pendidikan lebih lanjut. Maka dari itu pendidikan pada anak usia dini harus tetap dilaksanakan agar hak-hak anak dalam pendiikan tetap diterima oleh anak usia dini. Pembelajaran daring sangatlah berbeda dengan pelaksanaan pembelajaran konvensional. Perbedaan yang paling penting terletak ppada penggunaan media dimana pembelajaran tersebut dilakukan. Pangondian (2019) menjelaskan dalam pembelajaran konvensional memberikan pembelajaran dengan kontrol penuh terhadap lingkungan, materi serta interaksi antara guru dan siswa, sedangakan pada membelajaran online memberikan suatu pembelajaran yang dipisah dengan dunia maya sehingga kemampuan adaptasi serta perubahan-perubahan sudah tidak lagi tersedia.

Pelaksanaan pembelajaran daring yang ada pada PAUD sangatlah menguras tenaga agar pembelajaran dapat terealisasikan dengan baik. Dalam pembelajaran daring pada anak usia dini tentu terdapat problematika yang muncul dalam pelaksanaannya.

Problematika yang dihadapi dalam pelaksanaan daring sebagai berikut :

1. Sarana dan prasarana, pembelajaran yang sangat membutuhkan smartphone dan jaringan internet maka tidak semua wali murid atau orang tua dapat menggunakan. Hal ini sering ditemukan pada daerah pedesaan atau pada kalangan orang tua usia tua yang masih mempunyai anak usia dini.

2. Media pembelajaran, Pelalsanaan daring tidak memungkinkan adanya media pembelajaran yang jarang ditemukan dilingkungan keluarga. Maka guru harus memyesuaikan media yang dapat di temuakan di lingkungan keluarga agar tujuan dari pembelajaran dapat terealisasikan.

3. Komunikasi, Penjelasan yang kurang detai atau jelas membuat pemahaman setiap orang tua berbeda-beda sehingga menyampaikan kepada anak juga berbeda. Selain itu, karena semua yang serba online sehingga jaringan internet sibuk juga menghambat pembelajaran daring.

4. Waktu, Waktu juga merupakan problematikan yang dihadapi. Tidak semua orang tua berada dirumah atau standbye dengan anaknya. Maka dari itu sangat tidak mungkinkan untuk pelaksanaan daring sesuai dengan jadwal sekolah anaknya. 
Pangondian (2019) menjelaskan kelebihan dan kekurangan proses pelaksanaan pembelajaran daring. Kelebihan pada pelaksanaan daring antara lain pembelajaran terpusat dan melatih kemandirian anak, waktu dan lokasi yang fleksibel serta ases yang tidak terbatas dalam perkembangan pengetahuan. Sedagkan kekurangannya antara lain kurang cepatnya mpan balik dalam proses pembelajaran, mempersiapkan waktu yang tidak sekit dalam mempersiapkan, adanya ketidak nyamanan serta memicu perilaku frustasi, kecemasan dan kebingungan pada pihak yang bersangkutan.

Menurut Ghirardini (dalam Adhe, 2018) daring merupakan metode pembelajaran yang efektif, seperti berlatih secara mandiri, menggabungkan kolaborasi kegiatan dengan belajar mandiri, personalisasi pembelajaran berdasarkan kebutuhan siswa dan menggunakan simulasi serta permainan. Dan dengan ini semua siswa mendapatkan instruksi yang sama. terdapat dua pendekatan untuk pelaksanaan daring yang pertama adalah self paced dan yang kedua adalah facilitated / instructor- led, Ghirardini, (dalam adhe, 2018). siswa dengan pendekatan self paced, yaitu melaksanakan daring secara andiri, sedangkan pendekatan fasilitated/instructoe led pelaksanaan daring yang difasilitasi atau dipimpin oleh seorang instruktur daring yang mana dapat berkolaborasi dengan pihak lain. Menurut Ghirardini (2011) terdapat beberapa pendekatan yang dapat digunakan dalam pelaksanaan daring:

1. Daring content adalah daring dengan menggunakan bahan/sumber daya noninteraktif seperti dokumen, PowerPoint, video atau audio/voice note. Maksud dari non-interaktir adalah dimana siswa tidak dapat melakukan interkasi apapun kecuali hanya membaca, menonton atau memperhatikan isi dari daring.

2. Interaktif e-lesson yakni pendekatan yang biasanya digunakan dengan menggunakan pendekatan yang paling umum untuk self paced daring pelatihan berbasis web yang terdiri dari satu set interactive e-lessons. E-lessons mencakup teks, grafik, animasi, audio, video dan interaktivitas dalam bentuk pertanyaan dan umpan balik. E-lesson juga terdapat rekomendasi membaca dan link ke sumber daya lain, serta informasi tambahan tentang topik yang dibahas.

3. Simulasi elektronik adalah bentuk- bentuk yang sangat interaktif daring. Istilah simulasi pada dasarnya berarti menciptakan lingkungan belajar yang mensimulasikan dunia nyata, yang memungkinkan siswa untuk belajar dengan melakukan.

4. Job aids memberikan pengetahuan pada saat sekarang. Yang mana siswa dapat mengambil beberapa bentuk dan disampaikan pada platform yang berbeda. Pelaksana daring biasanya memberikan jawaban segera pada pertanyaan spesifik, sehingga membantu pengguna menyelesaikan tugas-tugas pekerjaan. Technical glossaries dan checklist adalah beberapa contoh dari job aids.

Menurut Siahaan (dalam Adhe, 2018) daring mempunyai tiga fungsi utama yakni: suplemen, komplemen, dan substitusi. Maksud dari fungsi suplemen adalah dimana daring dilakukan sebagai metode pemblejaran tambahan dalam pembelajaran maksudnya adalah diberikan sebagai tambahan materi yang diberikan untuk mendukung kegiatan pembekajaran sevara konvensional. Fungsi komplemen merupakan fungsi pelengkap dalam sebuah pembelajaran diluar dari pembelajaran klasikal. Sedangkan fungsi subtitusi adalah dimana daring merupakan pengganti pembelajaran dikelas dengan metode daring atau online. Mejadi pengganti secara keseluruhan yang mana pembelajaran klasikal diganti dengan pembelajaran daring. 
Parent and teacher collaboration merupakan istilah kerjasama antara orang tua dengan guru. Kata kolaborasi merupakan istilah yang memiliki makna ikut andil atau mempunyai peranan. Dimana tidak hanya guru sebagai pendidik anak untuk menyampaikan materi-materi dalam pembelajaran anak namun juga orang tua terlibat dalam proses pembelajaran. Orang tua turut terlibat dalam proses pembelajaran yang dilaksanakan oleh sekolah. Sehingga pembelajaran yang harus diterima oleh anak dapat tercapai dan tuntas.

Dalam pelaksanaannya kolaborasi antara orang tua dan guru ini mempunyai tugas pokok yang harus difahami oleh masing-masing antara sekolah, guru dan orang tua. Yang pertama adalah pengelola PAUD yang mempunyai tugas yaitu menganalisis kebutuhan siswa, menyediakan sarana dan prasarana, menyusun program, supervisi dan evaluasi. Yang kedua adalah guru yang mempunyai tugas menyusun program pendidikan, menyusun kerangka pembelajaran melaksanakan pembelajaran, mengevaluasi pembelajaran, melaporkan hasil evaluasi dan menjalin hubungan dengan orang tua. Sedangkan tugas orang tua adalah menciptakan suasana lingkungan belajar yang menyenangkan di rumah, mendorong perkembangan prestasi anak, menjalin komunikasi dan interaksi yang positif, hangat dan penuh kasih sayang dengan anak, memberikan dukungan serta menumbuhkan rasa percaya diri pada anak, menjalin hubungan dan komunikasi yang baik dan aktif dengan sekolah untuk memberikan informasi terkait perkembangan anak, men-support program sekolah dengan cara mengikuti dan menyediakan terkait sarana dan media pembelajaran serta menyelaraskan kegiatan anak di rumah dengan kegiatan di sekolahnya, selanjutnya orang tua harus proaktif untuk mendapatkan informasi terkait perkembangan anak dari guru, turut aktif dalam kegiatankegiatan sekolah yang bersangkutan dengan orang tua, serta turut andil dalam pengambilan keputusan dalam sekolah.

\section{RESEARCH METHOD}

Penelitian ini menggunakan jenis penelitian deskriptif kualitatif. Penelitian deskriptif merupakan metode penelitian yang digunakan untuk menggambarkan suatu fenomena yang terjadi dan disampaikan secara deskriptif.. Sumber data yang digunakan dalam penelitian ini adalah beberapa guru Paud yang ada di Sidoarjo sebagai respondent. Instrument yang digunakan dalam penelitian ini yaitu pedoman wawancara dan dokumentasi yang disampaikan melalui daring atau online. Teknik keabsahan data dalam penelitian menggunakan teknik triangulasi untuk menguji dan mengecek suatu kebenaran data yang telah didapat melalui wawancara, dan dokumentasi.

\section{RESULTS AND DISCUSSION}

Adapun hasil dan pembahasan dari implementasi kolaborasi orang tua dan guru dalam pelaksanaan pembelajaran daring pada PAUD sebagai berikut:

\section{Sudut pandang guru terhadap pembelajaran daring}

Pembelajaran daring merupakan proses pembelajaran yang dilakukan tanpa bertatap muka secara langung melainkan dengan menggunakan sebuah perangkat atau media. Perengkat atau media ini merupakan sebuah perangkat elektronik samartphone yang terhubung dengan jaringan internet. Narita Dwi menjelaskan pembelajaran daring meruakan Sistem pembelajaran online yang dilakukan oleh pendidik terhadap peserta didik guna menggantikan pembelajaran tatap muka seperti pada umumnya. Hal ini 
dibenarkan oleh Siahaan (dalam Adhe 2018) mejelaskan salah satu fungsi daring merupakan pembelajaran yang dilakukan secara online untuk menggantikan pembelajaran langsung atau dalam ruangan seperti biasanya. Dalam pelaksanaan daring guru harus bekerja sangat ekstra. Tidak jarang pula guru mendapti problematika pada pelaksanaan daring. Seperti yang dijelaskan oleh Syafitri (2020) juga menjelaskan guru mempunyai permasalahan dalam pelaksanaan daring salah satunya adalah tidak aktifnya beberapa anak dalam pembelajarn yang mana mengganggu keefektifan pembelajaran.

\section{Problematika dalam pembelajaran daring}

Guru merupakan tonggak utama dalam pelaksanaan pembelajaran daring. Terdapat beberapa problmatika yang dirasakan oleh guru dan orang tua dalam pelaksanaannya. Pembelajaran daring pada PAUD lebih efektif untuk penugasan, pembelajaran tidak dapat kondusif sehingga sulit untuk memantau perkembangan anak secara langsung, kurangnya sikap proaktif dari orang tua dalam pelaksanaan pembelajaran karena waktu orang tua yang kurang untuk mendampingi proses pembelajaran anak. Selain itu pelaksanaan daring yng bertujuan untuk memberikan pemahaman yang lebih intens juga mengalami problematika tersendiri seperti, lemahnya pemafaatan sarana dan prasarana atau media komunikasi dari pihak orang tua karena tidak semua notaben dari orang tua dapat mengoperasikan media komunikasi internet sesuai dengan pelaksanaan daring, ketidak adanya media pembelajaran dirumah, hingga lemahnya jaringan internet yang merupakan unsur utama dalam pelaksanaan daring. Hal demikian didukung oleh Pangondian (2019) terdapat beberapa faktor ang menjadi enentu keberhasilan pelaksanaan daring yaitu teknologi, karakteristik pengajar rofsional yang mana eran sentralnya menjadi penting dalam pelaksanaan daring, serta karakteristik siswa terkait kesiapan, kemampuan dan percaya diri dapat mendukung keberhasilan daring.

\section{Pelaksanaan pembelajaran daring}

Daring merupakan pembelajaran yang dilakukan dengan Bertatap muka secara langsung. Narinta Dwi menjelaskan pelaksanaan daring pada PAUD dilakukan dengan cara sebagai berikut :

a. Memberikan pengetahuan kepada orang tua mengenai program lembaga dalam pelaksanaan daring

b. Memberikan kisi-kisi pembelajaran setiap pagi.

c. Melakukan take Vidio (guru) untuk menjelaskan materi yang terkandung dalam kisi"

d. Pengumpulan jawaban dilakukan setiap hari.

e. Mengevaluasi setiap selesai KBM

Selain itu penerapan pembelajaran harus dibuat menyenangkan dan tidak membebani siswa namun tetap memperhatikan aspek-aspek perkembangannya. Hal ini didukung oleh Reni .Y selaku kepala Sekolah yang menyatakan melaksanakan pembelajaran rutin dirumah dengan kreasi masing- masing guru namun tetap mengarah pada kurtilas anak- anak dan harus sesuai dengan aspek- aspek yang akan dicapai dalam proses pembelajaran. Hal ini didukung oleh penjelasan Setyorini (2020) yang mnyatakan seorang guru mempunyai tanggung jawab dalam proses pendidikan anak sehingga pendidikan tetap berjalan. Seorang guru harus menemukan cara yang tepat dalam proses 
pembelajaran daring. Guru harus dapat mengelola kelas online dengan baik dan sesuai dengan materi yang ingin dicapai.

\section{Kolaborasi antara orang tua dan guru dalam pembelajaran daring.}

Kolaborasi antara orang tua dan guru sangat diperlukan dalam pelaksanaan daring. Dengan adanya kolaborasi ini proses pembelajaran tidak akan mengalami problematika yang serius. Kolaborasi ini diwujudkan dengan adanya komunikasi dan koordinasi yang rutin dan intens anatra guru dan orang tua. Partisipasi aktif guru dan orang tua dalam pelaksanaan pembelajaran daring juga mengamati perkembangan anak dalam pembelajaran anak. Guru dan Orang tua senantiasa melaksanakan tugas dan tanggung jawab dalam melaksanakan pendidikan melalui pemdampingan, motivasi dan pelaksanaan pembelajaran yang sesuai dengan kebutuhan anak. Nur, dkk (2016) menyatakan orang tua yang mempunyai peranan yang tinggi dalam memotivasikegiatan belajar anak yaitu orang tua yang ikut teribat dalam kegiatan belajar, mensupport, serta memberikan penghargaan kepada anak, memantau perkembangan akademik, sikap dan perilaku anak, serta menjalin kerjasama dengan sekolah dalam mengntrol perkembangan anak akan diikuti oleh motivasi belajar anak yang tinggi pula. Pernyataan ini selaras dengan Oni Taliawo (2019) yang menyatakan bentuk peranan hubungan kerja sama antara orang tua dan guru sangat menentukan minat belajara anak, kedisiplinan anak dalam proses belajar menentukan hasil yang maksimal, serta usaha-usaha yang dilakukan antara gur dan orang tua antara lain memotivasi, sealu memberikan bimbingan menciptakan suasana pmbelajaran yang menyenangkan. Selanjutnya Haerudin (2020) menjelaskan peran orang tua dalam prose pembelajaran daring dapat mempererat hubungan antara orang tua dan anak.

Pelaksanaan pembelajaran daring yang dilaksanakan berdasarkan kolaborasi antara orang tua dan guru dilakukan dengan langkah-langkah berikut: 1)Guru menyampaikan kepada orang tua terkait perkenalan proses pelaksanaan pembelajaran, memtofasi orang tua, menyampaikan materi sesuai dengan KD yang akan dilaksanakan hingga menjalin komunikasi. Selanjutnya orang tua sebagai pelaksana pembelajaran kepada anak dengan membimbing anak, ,melakukan pendampingan secara intens bersama anak dalam pelaksanaan daring, memfasilitasi media pembelajaran, hingga memberikan motivasi kepada anak untuk selalu bersemangat dalam proses belajar anak. 


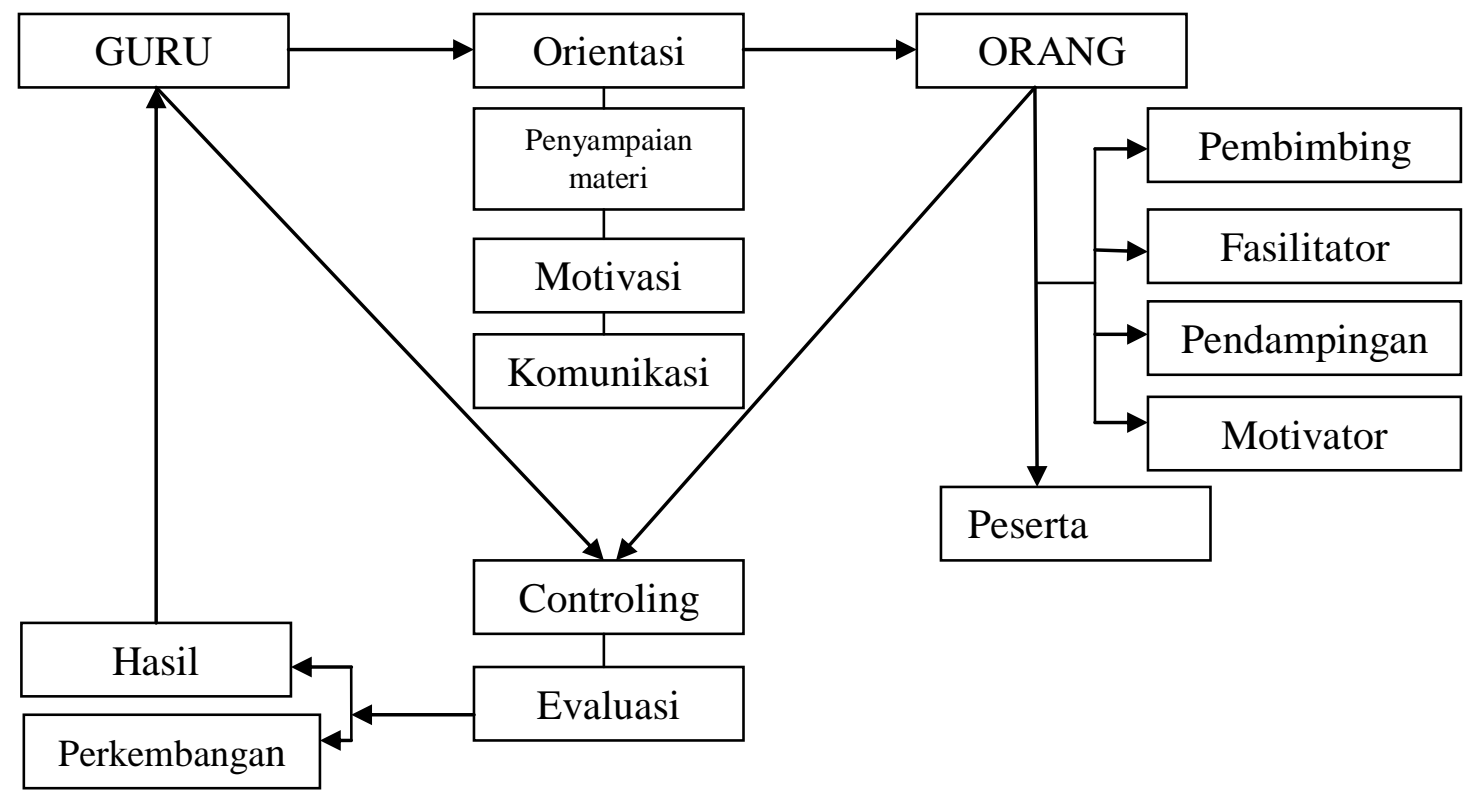

Skema 1 : pelaksanaan kolaborasi orang tua dan guru

Selanjutnya guru bersama orang tua selalu melakukan controling terhadap proses belajar anak dan melakukan evaluasi. Evaluasi yang disampaikan oleh orang tua kepada guru terdiri dari evaluasi hasil belajar setiap harinya dan evaluasi perkembangan anak. Dan guru dapat melakukan feedback kepada orang tua sehingga dapat mengetahui kekurangan dan kelebihan. Dari kekurangan dan kelebihan ini diharapkan pelaksanaan pembelajaran dapat berjalan lebih baik di hari selanjutnya. Pelaksanaan pembelajaran ini dapat dilihat melalui skema di bawah ini.

\section{CONCLUSIONS}

Dalam pelaksanaan pembelajaran daring sangat diperllukan adanya kolaorasi antara orang tua dan guru agar pembelajaran dapat berjalan dengan baik. Juga dengan adanya pelaksanaan daring ini peserta didik tetap memperoleh pendidikan dan materi sesuai dengan kompetensi yang hars dicapai. Pelaksanaan pembelajaran daring berbasis kolaborasi antara orang tua dan guru di awali dengan pemberian orientasi pada orang tua terkait pelaksanaan daring. Selanjutna guru memberikan materi pada anak yang diterima oleh orang tua, selanjutnya orang tua mengiplementasikan dengan pelaksanaan pembelajaran kepada anak yang dibimbing langsung oleh orang tua. Dengan adanya pembelajaran daring yang berbasis kolaborasi antara orang tua dan guru dapat memberikan motivasi kepada anak dalam kegiatan belajarnya. Sehingga anak dapat tuntas dalam tugas-tugas perkembangannya.

\section{ACKNOWLEDGEMENTS}

Peneliti mengucapkan terima kasih kepada PGMI FT IAI Al Khoziny Sidoarjo atas dukungan dan bantuan dalam hasil penelitian ini. 


\section{REFERENCES}

Adhe, Kartika. R. (2018). Model Pembelajaran Daring Matakuliah Kajian PAUD di Jurusan PG PAUD Fakultas Ilmu Pendidikan Universitas Negeri Surabaya. Yogjakarta. Jurnal Of Early Childhood Care And Education.

Driyani, Dwi dan Dewi Mustari. (2015). Model Pembelajaran Untuk Taman Kanak-Kanak Berbasis Web. Jakarta. Vol. 11, No.3.

Gomes, F. (2017). Parental Guidance Service: Kiat Meningkatkan Keterlibatan Orang Tua Dalam Paud. Flores. Jurnal Pendidikan dan Kebudayaan Missio. Vol. 9, No.1.

Haerudin, dkk. (2020). Peran Orang tua Dalam membimbing Anak Selama Pembelajaran Di Rumah Sebagai Upaya Memutus Covid-19. Karawang. Universitas Singaperbangsa Karawang.

Novela, Resi dan Yulsyofriend. (2019). Pelaksanaan Kolaborasi Guru Dan Orang Tua Dalam Perkembangan Anak Di Taman Kanak- Kanak Alam Minangkabau Padang. Padang. Selin Jurnal Program Study PGRA.Vol. 5, No 2.

Nur, dkk. (2016). Peran prang tua dalam memotivasi belajar siswa. Semarang. Indonesian Journal of guuidnce And Counseling. Vol. 5, No. 4.

Pangondian, R, A, Paulus Insap, P. Dkk. (2019). Faktor-Faktor Yang Mempengaruhi Pembelajaran Daring Dalam revolusi Industri. Yogyakarta, Seminar Nasional Teknologi Komputer \& Sains (SAINTEKS). Hal: 56-60

Pujiati, Hanip, dkk. (2018). Membangun Keterlibatan Orang Tua Dalam Pembelajaran Bahasa Inggris Di Paud Melalui Aplikasi Google Classroom Di Kecamatan Cibinong, Kabupaten Bogor. Pakuan. Prosiding Seminar Nasional PGSD. Hal 124-127.

Setyorini, In. (2020) Pandemi Covid-19 Dan Online Learning : Apakah Mempengaruhi Terhadap Proses Pembelajaran Pada Kurikulum 13?. Journal Of Industrial Engineering \& Management Research (JIEMAR). Vol :1, N0. 2.

Syafitri, Riska. Desi Purnama, S. dkk. (2020) Implementasi E-Learning Pada Mata Pelajaran Pendidikan Agama Islam Dimasa Pandemi Covid-19. Universitas Sumatera Utara. AL-ULUM Jurnal Pendidikan Islam. Vol. 1, No. 1.

Taliawo, Oni. dkk. (2019). Hubungan Kerjasama Antara Orang Tua Dan Guru Dalam Meningkatkan Minat Belajar Siswa di SMPN ATAP 1 Desa Buo Kecamatan Looda, Halmahera, Maluku Utara. ISSN : 1979-0481. Vol. 12, No. 4.

Author (s) :

* Moch. Surya Hakim Irwanto (Corresponding Author)

Department of Faculty Education,

Institute University of Islamic Al Khoziny Sidoarjo, Indonesia

Jl. KH. Khamdani, Siwalan Panji Buduran, Sidoarjo 61252, Indonesia

Email: hakimsurya4@gmail.com 